\title{
Entrepreneurship as an employment option for people with disabilities: Adding information to your job development toolkit $^{1}$
}

\author{
Lisa M. Svidron* \\ Associate Director of Employment Services, Mainstay Life Services, Roessler Road, Pittsburgh, PA, USA
}

Received 1 December 2020

Accepted 1 December 2020

\begin{abstract}
.
BACKGROUND: Traditional job development for people with disabilities involves placement of individuals into currently open community-based positions or customized positions in the community.

OBJECTIVE: When an individual expresses the desire to be self-employed and grow their own business, job developers are unaware of the opportunities available to assist in the process. Entrepreneurship or self-employment has been achieved by many notorious businessmen throughout time. These businessmen all have a disability in which they have learned to embrace their strengths and receive assistance for their weaknesses.

CONCLUSIONS: Lessons can be learned from the top businessmen to assist job developers in developing self-employment and entrepreneurship for their individuals to build a better job development toolbox.
\end{abstract}

Keywords: Employment, self-employment, entrepreneurship, disabilities, job development

\section{Background}

Employment first is relatively new terminology in the Supported Employment Industry. This concept has been a priority for the U.S. Department of Labor, Office of Disability Employment Policy

\footnotetext{
${ }^{1}$ This research was compiled and presented during the 2020 Association of People Supporting Employment First (APSE) Conference.

*Address for correspondence: Lisa Svidron, Associate Director of Employment Services, Mainstay Life Services, 200 Roessler Road, Pittsburgh, PA 15220, USA. E-mail: 1svidron@ mainstaylifeservices.org.
}

(ODEP) in order to promote full integration into the community and employment for those with disabilities. The Employment First movement has been gaining strength as more and more states adopt the movement to promote employment for all regardless of their abilities. The framework for Employment First states, "Change that is centered on the premise that all citizens, including individuals with significant disabilities, are capable of full participation in integrated employment and community life" (ODEP). Employment First by definition promotes a fully integrated typical work setting. A typical work setting can also include self-employment as the idea of selfemployment is full inclusion in the community. 


\subsection{Self-employment}

Self-employment or entrepreneurship is argued that, "Entrepreneurship may lead to breaking down barriers faced by people with disabilities and provide them with opportunities that traditionally are viewed as not possible or unattainable given the constraints of finding employment" (Maritz \& Laferriere, 2016). The use of self-employment or entrepreneurship has created opportunities to fill workforce gaps and ongoing shortages in the business world (Maritz $\&$ Laferriere, 2016). The use of self-employment to fill those shortages has provided a socially exclusive atmosphere in which those with disabilities can own and operate their own businesses.

Opening a business presents many challenges for those seeking self-employment. Those challenges can be more pronounced for those with a disability seeking self-employments. Entrepreneurs with disabilities may feel discriminated against by financial institutions or face challenges due to educational deficits (Maritz \& Laferriere, 2016). The greatest challenge for people with disabilities is the fear of losing their benefits.

Individuals may choose not to pursue self-employment due to the potential loss of benefits. Choosing self-employment may risk their social security income, medical benefits, and other supports set in place to provide daily living skills. Many individuals find self-employment to risky and choose to seek community-based employment instead. However, with good benefit counseling and encouragement, self-employment may completely or exceed the financial benefits that are being received through social security.

People with disabilities can succeed to become a top entrepreneur in today's business world. We can learn valuable lessons from successful businessmen that have not let their disability hold them back from obtaining the dreams that desire.

\section{Top entrepreneurs with a disability}

Top entrepreneurs in the business industry provide a look into their disabilities and how they overcame them to become successful with their organizations. They learned how to utilize their gifts and delegate their weaknesses to form profitable companies. The advice that they provide can be added to a Job Developers Toolbox and pulled out when working with those seeking entrepreneurship as an employment option.

\subsection{Daymond john}

Daymond John is founder of the Shark Group, Owner and CEO of FUBU, an Investor on Shark Tank, Consultant, Public Speaker, Author, and Founder of next Level Success Group. He has accomplished great success in the business world all while battling his poor spelling and poor reading comprehension due to Dyslexia. Growing up, he excelled in science and math as a kid but struggled with any subjects that involved reading and writing. As he joined the business world, his struggled to compose emails and business letters in a professional cohesive manner. When Daymond John started his first business, FUBU, he ensured that his staff understood all his written communication prior to carrying out the document. FUBU allowed John to utilize his visual side which involved his creativity and mapping numbers out in his head. He utilized his strengths to delegate and visuality to carry his business to a $\$ 350$ milliondollar peak annual revenue. He encouraged others to not hide behind their disability or to be ashamed by it (https://www.businessinsider.com).

\subsection{Richard branson}

Richard Branson is the founder of the Virgin Group which controls over 400 companies in various fields. In 1970 he started a mail order record business and Virgin Records which signed well known artists. His business resume included being named as one of the 100 most influential people in the world by Time Magazine and the founder of space travel companies. Branson's idea of making a positive change to the world guided his business choices and opportunities. However, he struggled with dyslexia both growing up and in the workplace.

Branson utilized his skills of creativity, problem solving and imagination to build a company of the future. His deficits were delegated to others that showed those skills as their strengths. He led the company to success using his skill set and the help of his staff where he continues to use the same skills to run his company today (https://www.virgin.com/richardbranson).

\subsection{Bram cohen}

Bram Cohen is the founder of BitTorrent which allows individuals to share large quantities of data 
Table 1

Investigation Board - Assessing skills and interests

\begin{tabular}{ll}
\hline Likes & Dislikes \\
Hobbies & Interests \\
\hline
\end{tabular}

across the internet. His brain allows for complex solving of puzzles and problem solving to provide a unique perspective on the issue. Bram was diagnosed with Asperger's. Growing up, he struggled to fit in with people in a social manner and felt isolated. By 16 years of age, he could code in three languages. He showed he was gifted on the computer as a programmer which made him quite happy.

After creating BitTorrent, Bram became notorious in the computer industry. He was asked to speak at computer conventions and universities. Social situations continuously plagued him due to his disability. His wife became was his encouragement as he learned how to overcome his struggles in social situations. Today he states that his Asperger mind is his strength that helps his success. His brain thinks differently from those around him offering the opportunity to have a different look at the same problem (https://freenterprise.com/entrepreneurs-withlearning-disabilities/).

\section{Job development toolkit for entrepreneurs}

Utilizing the examples from the three entrepreneurs that have found success regardless of their disability can assist in helping entrepreneurs today. During the first meeting with a new individual seeking employment, it is important to figure out their likes, dislikes, hobbies, interests. Utilizing the Investigation Board (see Table 1, for Investigation Board) we can visually organize the individual's preferences in order to seek employment. It is from this board that we will see if entrepreneurship is attainable and viable for the job seeker. If entrepreneurship has been expressed, then additional probing will need to be conducted to obtain the level of interest.

John, Branson and Bram all utilized their strong skill sets to achieve their business success. They capitalized on their strengths such as creativity, visual tasking and skill sets that others did not have in order to successfully start their companies. They all delegated their weaknesses to others that possess that as a strength. This idea propelled their companies into profitable sectors in the business communities. By focusing on the strengths of job seeking clients, we can assess whether entrepreneurship is a viable option for them.

\section{Funding for entrepreneurs with disabilities}

Funding for entrepreneurs is an area that scares most people looking into self-employment. Money is needed in order to start and preserve the business into the future. Prior to obtaining funding, it is important to work together to write a business plan. The business plan will provide a written plan for the entire business including funding needed, marketing, communications, permits, licenses, costs of doing business, projected revenue and a 5-year budget. This will be required of any external funding sources. Templates for the business plan can be found on the sba.gov website or through the local SBA (Small Business Administration) Office. Additional opportunities outside of financial institutions will vary state-to-state. Vocational Rehabilitation offices are aware of financial opportunities that exist locally and on higher funding levels. Social Security also provides a grant program that may assist in funding sources. Regardless of the funding source used it is important to keep an open communication regarding benefits that may be affected once self-employment is obtained.

\section{Conclusion}

The Employment First movement has been on the rise over the past few years as more states adopt the idea of full integration into the community for people with disabilities. As the movement continues, it is important to recognize that self-employment or entrepreneurship is a valuable piece of Employment First. Self-employment promotes social integration and self-empowerment to live viably in a community. Assessing a person for self-employment attainability is an important tool to use in the Job Development Toolbox. John, Branson and Cohen suggested using the skills that one is gifted with as a strength in the business and delegating the weaknesses. However, it is vital to understand what the strengths and weaknesses are for each individual supported. The assessment tool in the toolbox will assist a Job Developer in finding those special skills and steering away from those that will not help in business. Once a business is identified it is important to write a business plan and seek funding that works for the individual 
supported. As with all job developing pieces, it is necessary that an open line of communication remains between the job developer, the person supported, and other individuals involved in the team of support. Self-employment is a possibility when strengths are capitalized to provide a business opportunity that matches the skill set of the person supported.

\section{Conflict of interest}

None to report.

\section{References}

Feloni, R. (2015, December). 'Shark Tank' investor Daymond John explains how his dyslexia helped shape him into an entrepreneur. Business Insider. Retrieved from https:// www.businessinsider.com/shark-tank-daymond-john-on-dysl exia-and-success-2015-12?utm_source=copy-link\&utm_me dium=referral\&utm_content=topbar.

Free Enterprise Staff (2016, July 12). The 4 ridiculously successful entrepreneurs you didn't know have learning disabilities. Free Enterprise. Retrieved from https://freeenterprise. com/entrepreneurs-with-learning-disabilities/

Maritz, A., \& Laferriere, R. (2016). Entrepreneurship and self-employment for people with disabilities. Australian Journal of Career Development, 25(4), 45-54. doi: 10.1177/ 1038416216658044

Virgin. (n.d.). Richard Branson. https://virgin.com/bransonfamily/richard-branson 